\title{
OBESITY AS ENVIRONMENTAL RISK FACTOR FOR REPEATED PREGNANCY LOSS IN PATIENTS WITH ANTIPHOSPHOLIPID SYNDROME
}

El-Bokary, M. S. ${ }^{(1)}$; Salah El-Din, S. M. ${ }^{(2)}$ and Hathhout, Azza, M.

1) Institute of Environmental Studies and Research, Ain Shams University

2) Obstetrics and Gynecology department, Obstetrics, and Gynecology department, Faculty of medicine, MenofieyaUniversity

\begin{abstract}
Introduction: Antiphospholidsyndrome (APS) is an autoimmune hypercoagulablestate caused by antiphospholid antibodies. Primary antiphospholipidsyndrome occurs in absence of any other related disease. Secondary antiphospholipid syndrome occurs with other autoimmune disease as systemic lupus erythrematosis. The clinical features of the APS are various, but the most common clinical presentation is pregnancy loss, DVT. Pulmonary thromboembolism, the cardiac manifestations of APS include myocardial infarction, pericardial effusion, myocardiopathy, and coronary artery thrombosis, but the most common manifestation is valvular abnormalities.

Aim: to investigate the influence of obesity in women diagnosed as an antiphospholipid cases according to Sydney's criteria on pregnancy morbidities, vascular events, pulmonary thromboemboism and laboratory criteria.

Methods: A case control study was conducted that include women attending obstetric outpatient clinic. These women were previously diagnosed as antiphospholipid cases according to (Sydney's criteria).A total of 60 women have been equally divided into two groups: First group corresponds to control group which includes 30 women with normal body mass index (BMI) i.e. < $30 \mathrm{Kg} / \mathrm{m} 2$ and, second group include 30 obese women with (BMI > $30 \mathrm{Kg} / \mathrm{m} 2)$.
\end{abstract}

Results: Obesity is independent predictor for preterm birth intrauterine fetal death and pulmonary thromboembolism. 
Conclusion: Obesity is associated with worth pregnancy outcomes in patients with primary antiphospholipid syndrome.

Keywords: Antiphospholipid syndrome, Obesity, Pregnancy morbidities, Vascular events, Pulmonary thromboembolism, Antiphospholipid antibodies.

\section{INTRODUCTION}

The antiphospholipid syndrome (APS) is an autoimmune disease characterize by arterial and venous thrombosis due to antiphospholipid antibodies. The disorder is referred to as primary when it occurs in the absence of another autoimmune disease. Secondary APS occurs in the context of an autoimmune disorder such as systemic lupus erythematosus. The catastrophic APS (CAPS) is a rare life-threatening form of APS in which widespread intravascular thrombosis results in multiorgan ischemia and failure (Cervera et al., 2009 ;Nayer and Ortega, 2014).

The other major clinical manifestations of the antiphospholipid syndrome are obstetrical. They include the unexplained death of one or

more morphologically normal fetuses at or beyond the 10th week of gestation, the premature birth of one or more morphologically normal fetuses before the 34th week of gestation because of either eclampsia or severe preeclampsia, and three or more unexplained, consecutive spontaneous abortion before the10thweek of gestation (Lochshin et al.,2006; Giannakopoulos and Krilis,2013).

These Cases with poor obstetric outcome are known to have obstetric antiphospholipid syndrome (OAPS) (Alijotas-Reig et al., 2012; Alijotas-Reig et al.,2014).

The clinical features of the APS are various, but the most common 60 
clinical presentation is pregnancy loss, deep venous thrombosis (DVT) (Cervera et al., 2002; Ye et al., 2005). Pulmonary thromboembolism, the cardiac manifestations of APS included (myocardial infarction, pericardial effusion, myocardiopathy, and coronary artery thrombosis, but the most common manifestation is valvular abnormalities) (Espisonsa et al., 2002; Ye et al.,2005).

\section{AIM OF THE WORK}

The aim of the current study is to investigate the influence of obesity in women diagnosed as having antiphospholipid syndrome (according to Sydney's criteria) on pregnancy morbidities, vascular events, and pulmonarythromboemboism and laboratory criteria.

\section{PATIENTS AND METHODS}

A case control study was conducted that include women attending obstetric outpatient clinic. These women were previously diagnosed as antiphospholipid cases according to (Sydney's criteria).

Due to scarcity of antiphosphoipid cases, women participating in this current study were collected from outpatient clinic of three hospitals, Boulak El Dakror General Hospital, Embaba General Hospital and Om Elmasrein GeneralHospital.

The period of the study was about 24 months from august 2015 till August 2017.

Thrombotic events both venous and arterial of every patient were analyzed, pregnancy morbidities included in Sydney's classification were evaluated also laboratory investigations included in Sydney's criteria were 
examined and then among 200 patient with antiphospholipid syndrome attending the outpatient clinics of the three hospitals, 60 patients were selected to participate in this study.

A written consent to take part in the study was obtained. Refusal to participate in the study was an obvious exclusion criteria.

Inclusion Criteria: Women who were previously diagnosed as having antiphospholipid syndrome as described by Sydney's criteria.

According to Sydeny's criteria; APS is diagnosed when at least one of the following clinical criteria and one of the following laboratory criteria are met.

\section{Laboratory Criteria:}

1) Lupus anticoagulant (LA) present in plasma, on two or more occasions at least 12 weeks apart, detected according to the guidelines of the International Society on Thrombosis and Haemostasis.

2) Anticardiolipin (aCL) antibody of $\mathrm{IgG}$ and/or IgMisotype in serum or plasma, present in medium or high titer, on two or more occasions, at least 12 weeks apart, measured by standardized ELISA.

3) Anti 2 glycoprotein-1 antibody of $\operatorname{IgG}$ and/or IgMisotype in serum or plasma (in titer $>99$ th percentile), present on two or more occasions, at least 12 weeks apart, measured by standardized ELISA (Marchetti et al.,2013). 


\section{Clinical Criteria:}

1) 1 unexplained fetal deaths $\geq 10$ weeks of gestation with normal anatomy by prenatal ultrasound examination or direct postnatalexamination.

2) $\geq 1$ preterm deliveries of a morphologically normal infant before 34 weeks of gestation due to severe preeclampsia, eclampsia, or features consistent with placentalinsufficiency.

3) $\geq 3$ unexplained, consecutive, spontaneous pregnancy losses $<10$ weeks of gestation, after exclusion of maternal anatomic and hormonal abnormalities and paternal and maternal chromosomal abnormalities (Charles \& Michael, 2017).

\section{Exclusion Criteria:}

- Women who didn't have obstetric morbidities or have obstetric morbidities but were not as described in Sydney's criteria.

- Women with pregnancy losses explained by infectious, metabolic, anatomical or hormonal factors or maternal and paternal chromosomaldiseases.

- Women with history of hepatitis B virus, hepatitis C virus or human immunodeficiency virus infection as well as those with non-organ systemic autoimmunedisease.

- Women with negative laboratory criteria as described in Sydney'scriteria.

A total of 60 women have been equally divided into two groups: First group corresponds to control group which includes 30 women with normal BMI i.e. $<30 \mathrm{Kg} / \mathrm{m} 2$ and are not smokers, second group include 30 obese women with (BMI > $30 \mathrm{Kg} / \mathrm{m} 2)$. 


\section{All eligible patients were submitted to the following:}

\section{1) Careful historytaking:}

- Age and duration ofdisease.

- Number of full termpregnancy. 3- Number of earlymiscarriage.

- Number of midtrimestericabortions.

- Number of preterm deliveries of morphologically normal infantbefore 34 weeks of gestation due to severe preeclampsia, elcampsia or features consistent with placental insufficiency.

- Unexplained fetal death or stillbirth

- Unexplained second or third trimester fetaldeath.

- Full data about any previous thrombotic event either venous orarterial

\section{2) Clinicalexamination}

- General and abdominal examination: to exclude any medicalproblem.

- Gynecological examination; to exclude any gynecological cause of pregnancymorbidities.

- Laboratory investigations: laboratory assay foranti-

- phospholipid antibodies (apL) in two occasions at least 12 weeks apart.

- The resultant data was tabulated and statistical analysis wasdone.

\section{STATISTICAL METHODS}

Data were analyzed using SPSS $\odot$ Statistics version 23 (IBM@ Corp., Armonk, NY, USA).

Categorical variables were presented as number and percentage and between-group differences were compared using Fisher's exact test. 
Normality of numerical data distribution was examined using the Shapiro-Wilk test. Normally distributed numerical variables were presented as mean $\pm \mathrm{SD}$ and inter-group differences were compared using one-way analysis of variance (ANOVA) with application of the Tukey-Kramer test for multiple Pairwise comparisons if there was a statistically significant difference among thegroups.

Multivariable binary logistic regression analysis was used to examine the relation between obesity and individual disease manifestations or outcomes as adjusted for other confoundingfactors.

Two-sided p-value $<0.05$ was considered statistically significant.

\section{RESULTS}

Table (1): Relation between obesity and manifestations ofdisease

\begin{tabular}{||l|c|c|c||}
\hline \multicolumn{1}{|c|}{ Variable } & Non-obese $(\mathbf{n = 3 0})$ & Obese (n=30) & p-value* \\
\hline \hline Age (years) & $28.5 \pm 7.4$ & $27.5 \pm 7.9$ & 0.530 \\
\hline Duration of disease (months) & $57.0 \pm 39.0$ & $89.2 \pm 68.6$ & 0.022 \\
\hline Recurrent early miscarriage(REM) & $28(46.7 \%)$ & $16(53.3 \%)$ & 0.656 \\
\hline Premature birth (PMB) & $21(35.0 \%)$ & $15(50.0 \%)$ & 0.181 \\
\hline Intrauterine fetal death (IUFD) & $24(40.0 \%)$ & $17(56.7 \%)$ & 0.179 \\
\hline Pulmonary thromboembolism(PTE) & $17(28.3 \%)$ & $13(43.3 \%)$ & 0.165 \\
\hline Vascular events & $18(30.0 \%)$ & $9(30.0 \%)$ & 1.000 \\
\hline +ve Lupus anticoagulant (LAC) & $52(86.7 \%)$ & $16(53.3 \%)$ & 0.001 \\
\hline +veAnticardiolipin (aCL) IgG & $39(65.0 \%)$ & $15(50.0 \%)$ & 0.181 \\
\hline +veAnticardiolipin (aCL) IgM & $36(60.0 \%)$ & $19(63.3 \%)$ & 0.821 \\
\hline $\begin{array}{l}\text { Anti } \beta 2 \text { glycoprotein-1 IgG and/or } \\
\text { IgM }\end{array}$ & $43(71.7 \%)$ & $22(73.3 \%)$ & 1.000 \\
\hline
\end{tabular}

Data are mean \pm SD or number (\%).

*Unpaired t-test (for continuous data) or Fisher's exact test for categorical data. 
J. Environ. Sci.

Institute of Environmental Studies and Research - Ain Shams University

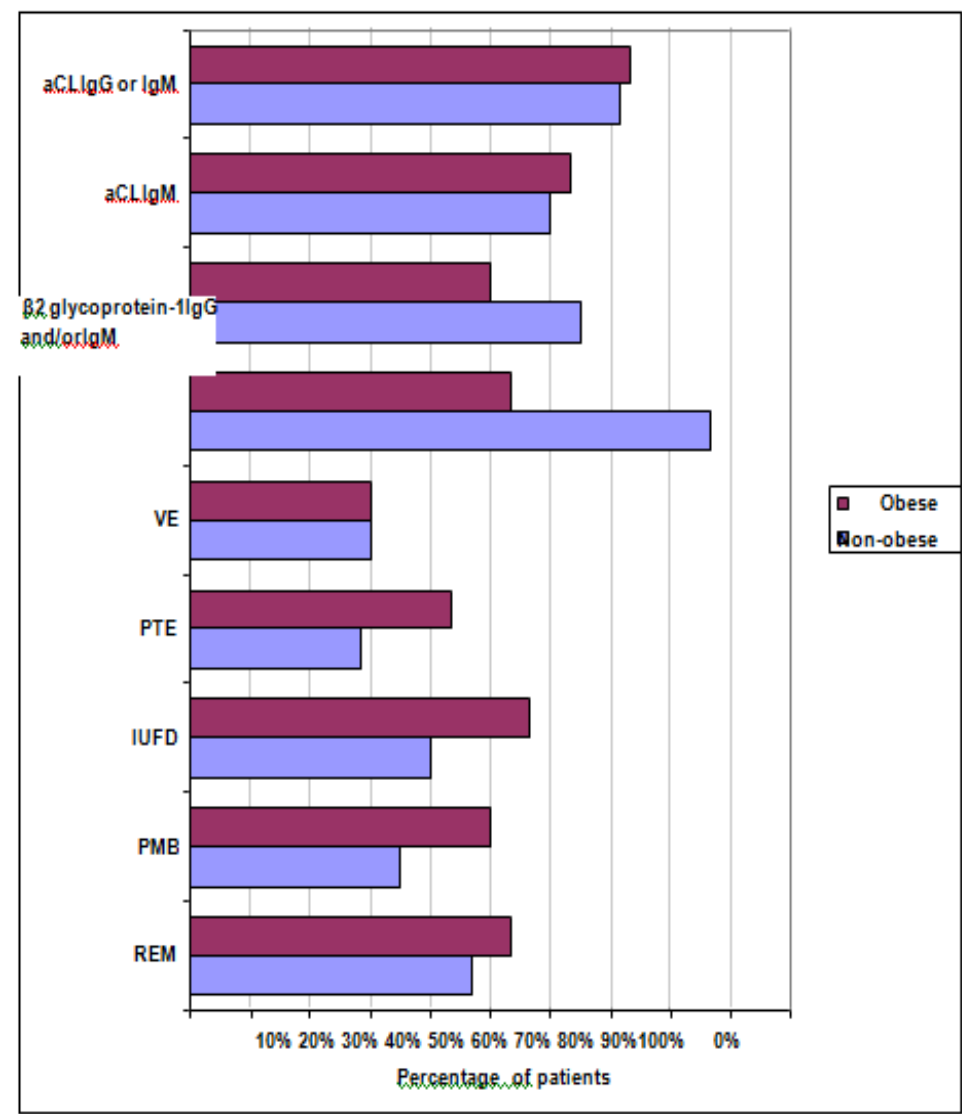

Figure (1): Prevalence of the various disease features in obese and non-obese patients.

LAC : Lupus Anti Coagulant

PTE : Pulmonary thromboembolism

PMB: Premature birth
VE: Vascular Event

IUFD: Intrauterine fetal death REM: Recurrent Early Miscarriage 
Table (2): Multivariable binary logistic regression analysis for the relation between obesity and recurrent early miscarriage as adjusted for other confoundingfactors

\begin{tabular}{|l|c|c|c|c|c|c|}
\hline \multicolumn{1}{|c|}{ Variable } & B & SE & Wald & p-value & $\begin{array}{c}\text { Odds } \\
\text { ratio }\end{array}$ & 95\% CI \\
\hline \hline $\begin{array}{l}\text { Age (years) } \\
\begin{array}{l}\text { Disease duration } \\
\text { (months) }\end{array}\end{array}$ & -0.072 & 0.042 & 2.965 & 0.085 & 0.930 & 0.857 to 1.010 \\
\hline \begin{tabular}{l} 
Obesity \\
\hline Constant
\end{tabular} & 0.942 & 0.657 & 2.054 & 0.152 & 2.566 & 0.707 to9.306 \\
\hline
\end{tabular}

$\mathrm{B}=$ regression coefficient, $\mathrm{SE}=$ standard error, Wald $=$ Wald statistic, 95\% $\mathrm{CI}=$ $95 \%$ confidence interval.

After adjustment for other variables, obesity was not an independent predictor for REM

Table (3): Multivariable binary logistic regression analysis for the relation between obesity and premature birth as adjusted for other confoundingfactors

\begin{tabular}{|l|c|c|c|c|c|c|}
\hline & B & SE & Wald & p-value & $\begin{array}{c}\text { Odds } \\
\text { ratio }\end{array}$ & 95\% CI \\
\hline \hline Age (years) & -0.145 & 0.053 & 7.629 & 0.006 & 0.865 & 0.780 to0.959 \\
\hline $\begin{array}{l}\text { Disease duration } \\
\text { months) }\end{array}$ & -0.007 & 0.008 & 0.667 & 0.414 & 0.993 & 0.977 to 1.010 \\
\hline Obesity & 1.791 & 0.763 & 5.514 & 0.019 & 5.998 & 1.345 to 26.752 \\
\hline Constant & 2.766 & & & & & \\
\hline
\end{tabular}

$\mathrm{B}=$ regression coefficient, $\mathrm{SE}=$ standard error, Wald $=$ Wald statistic, $95 \% \mathrm{CI}=$ $95 \%$ confidence interval.

After adjustment for other variables, younger age (odds ratio $=0.865$, $95 \% \mathrm{CI}=0.780$ to $0.959, \mathrm{p}$-value $=0.006)$, obesity $($ odds ratio $=5.998,95 \%$ $\mathrm{CI}=1.345$ to 26.752 , $\mathrm{p}$-value $=0.019$ ) was independent predictors for PMB. 
J. Environ. Sci.

Institute of Environmental Studies and Research - Ain Shams University

Table (4): Multivariable binary logistic regression analysis for the relation between obesity and intrauterine fetal death as adjusted for other confoundingfactors

\begin{tabular}{|l|c|c|c|c|c|c|}
\hline \multicolumn{1}{|c|}{ Variable } & B & SE & Wald & p-value & $\begin{array}{c}\text { Odds } \\
\text { ratio }\end{array}$ & 95\% CI \\
\hline Age(years) & 0.128 & 0.054 & 5.603 & 0.018 & 1.137 & 1.022 to 1.264 \\
\hline $\begin{array}{l}\text { Disease duration } \\
\text { (months) }\end{array}$ & -0.001 & 0.007 & 0.034 & 0.854 & 0.999 & 0.984 to 1.013 \\
\hline Obesity & 2.311 & 0.905 & 6.522 & 0.011 & 10.087 & 1.712 to59.448 \\
\hline Constant & -5.376 & \multicolumn{5}{|l}{} \\
\hline
\end{tabular}

$\mathrm{B}=$ regression coefficient, $\mathrm{SE}=$ standard error, Wald $=$ Wald statistic, $95 \% \mathrm{CI}=$ 95\% confidence interval.

After adjustment for other variables, older age (odds ratio $=1.137,95 \%$ $\mathrm{CI}=1.022$ to $1.264, \mathrm{p}$-value $=0.018)$, obesity $($ odds ratio $=10.087,95 \% \mathrm{CI}=$ 1.712 to $59.448, \mathrm{p}$-value $=0.011)$ was independent predictors for IUFD.

Table (5): Multivariable binary logistic regression analysis for the relation between obesity and pulmonary thromboembolism as adjusted for other confoundingfactors

\begin{tabular}{|l|c|c|c|c|c|c|}
\hline \multicolumn{1}{|c|}{ Variable } & B & SE & Wald & $\begin{array}{c}\text { p- } \\
\text { value }\end{array}$ & $\begin{array}{c}\text { Odds } \\
\text { ratio }\end{array}$ & 95\% CI \\
\hline $\begin{array}{l}\text { Age (years) } \\
\begin{array}{l}\text { Disease duration } \\
\text { (months) }\end{array}\end{array}$ & 0.249 & 0.075 & 10.965 & 0.001 & 1.283 & 1.107 to 1.487 \\
\hline Obesity & -0.007 & 0.009 & 0.665 & 0.415 & 0.993 & 0.976 to 1.010 \\
\hline Constant & -10.255 & 1.321 & 7.873 & 0.005 & 40.690 & 3.057 to 541.690 \\
\hline
\end{tabular}

$\mathrm{B}=$ regression coefficient, $\mathrm{SE}=$ standard error, Wald $=$ Wald statistic, $95 \% \mathrm{CI}=$ 95\% confidence interval.

After adjustment for other variables, older age (odds ratio $=1.283,95 \%$ $\mathrm{CI}=1.107$ to $1.487, \mathrm{p}$-value $=0.001)$, obesity $($ odds ratio $=40.690,95 \% \mathrm{CI}=$ 3.057 to 541.690, $\mathrm{p}$-value $=0.005$ was independent predictors for PTE. 
Table (6): Multivariable binary logistic regression analysis for the relation between obesity and vascular events as adjusted for other confoundingfactors

\begin{tabular}{|c|c|c|c|c|c|c|}
\hline Variable & B & SE & Wald & p-value & $\begin{array}{c}\text { Odds } \\
\text { ratio }\end{array}$ & 95\% CI \\
\hline \hline Age (years) & 0.006 & 0.042 & 0.022 & 0.882 & 1.006 & 0.927 to 1.092 \\
\hline $\begin{array}{c}\text { Disease duration } \\
\text { (months) }\end{array}$ & 0.003 & 0.006 & 0.294 & 0.588 & 1.003 & 0.991 to 1.016 \\
\hline Obesity & -0.008 & 0.702 & 0.000 & 0.991 & 0.992 & 0.251 to 3.930 \\
\hline Constant & -1.329 & & & & & \\
\hline
\end{tabular}

$\mathrm{B}=$ regression coefficient, $\mathrm{SE}=$ standard error, Wald $=$ Wald statistic, $95 \% \mathrm{CI}=$ 95\% confidence interval.

After adjustment for other variables, obesity was not an independent predictor for vascular events (all p-values $>0.05$ ).

Table (7): Multivariable binary logistic regression analysis for the relation between obesity and positive lupus anticoagulant test as adjusted for other confoundingfactors

\begin{tabular}{||l|c|c|c|c|c|c||}
\hline \multicolumn{1}{|c|}{ Variable } & B & SE & Wald & p-value & $\begin{array}{c}\text { Odds } \\
\text { ratio }\end{array}$ & 95\% CI \\
\hline \hline $\begin{array}{l}\text { Age (years) } \\
\text { Disease duration } \\
\text { (months) }\end{array}$ & 0.060 & 0.052 & 1.313 & 0.252 & 1.062 & 0.959 to 1.176 \\
\hline Obesity & -0.014 & 0.008 & 3.188 & 0.074 & 0.986 & 0.970 to 1.001 \\
\hline Constant & -0.706 & 0.736 & 0.920 & 0.338 & 0.494 & 0.117 to2.090 \\
\hline
\end{tabular}

$\mathrm{B}=$ regression coefficient, $\mathrm{SE}=$ standard error, Wald $=$ Wald statistic, $95 \% \mathrm{CI}=$ 95\% confidence interval.

After adjustment for other variables, obesity was not an independent predictor for a positive LAC test (all p-values $>0.05$ ). 
Table (8): Multivariable binary logistic regression analysis for the relation between obesity and positive anticardiolipinIgG test as adjusted for other confoundingfactors

\begin{tabular}{|l|c|c|c|c|c|c|}
\hline \multicolumn{1}{|c|}{ Variable } & $\mathbf{B}$ & $\mathbf{S E}$ & Wald & $\mathbf{p}$-value & $\begin{array}{c}\text { Odds } \\
\text { ratio }\end{array}$ & 95\% CI \\
\hline Age (years) & -0.002 & 0.039 & 0.002 & 0.962 & 0.998 & 0.925 to 1.077 \\
\hline $\begin{array}{l}\text { Disease duration } \\
\text { (months) }\end{array}$ & 0.001 & 0.006 & 0.012 & 0.913 & 1.001 & 0.989 to 1.013 \\
\hline Obesity & -0.583 & 0.636 & 0.841 & 0.359 & 0.558 & 0.161 to1.942 \\
\hline Constant & 0.576 & & & & & \\
\hline
\end{tabular}

$\mathrm{B}=$ regression coefficient, $\mathrm{SE}=$ standard error, Wald $=$ Wald statistic, $95 \% \mathrm{CI}=$ 95\% confidence interval.

After adjustment for other variables, obesity was not an independent predictor for a positive aCLIgG test (all p-values >0.05).

Table (9): Multivariable binary logistic regression analysis for the relation between obesity and positive anticardiolipinIgMtest as adjusted for other confoundingfactors

\begin{tabular}{|c|c|c|c|c|c|c|}
\hline Variable & $\mathbf{B}$ & SE & Wald & p-value & $\begin{array}{c}\text { Odds } \\
\text { ratio }\end{array}$ & 95\% CI \\
\hline \hline Age (years) & -0.005 & 0.040 & 0.016 & 0.899 & 0.995 & 0.920 to 1.076 \\
\hline $\begin{array}{c}\text { Disease duration } \\
\text { (months) }\end{array}$ & 0.011 & 0.007 & 2.381 & 0.123 & 1.011 & 0.997 to 1.025 \\
\hline Obesity & -0.346 & 0.649 & 0.284 & 0.594 & 0.708 & 0.199 to 2.523 \\
\hline Constant & 0.134 & & & & & \\
\hline
\end{tabular}

$\mathrm{B}=$ regression coefficient, $\mathrm{SE}=$ standard error, Wald $=$ Wald statistic, $95 \% \mathrm{CI}=$ 95\% confidence interval.

After adjustment for other variables, obesity was not an independent predictor for a positive aCLIgM test (all p-values >0.05). 
Table (10): Multivariable binary logistic regression analysis for the relation between obesity and positive anti- $\beta 2$ glycoprotein-1 $\operatorname{IgG}$ and /or $\operatorname{IgM}$ test as adjusted for other confounding factors

\begin{tabular}{||c|c|c|c|c|c|c||}
\hline Variable & B & SE & Wald & p-value & $\begin{array}{c}\text { Odds } \\
\text { ratio }\end{array}$ & 95\% CI \\
\hline \hline Age (years) & -0.003 & 0.041 & 0.005 & 0.945 & 0.997 & 0.920 to 1.0813 \\
\hline $\begin{array}{c}\text { Disease duration } \\
\text { (months) }\end{array}$ & 0.000 & 0.007 & 0.004 & 0.950 & 1.000 & 0.987 to 1.013 \\
\hline Obesity & 0.334 & 0.688 & 0.235 & 0.628 & 1.396 & 0.362 to5.383 \\
\hline Constant & 0.793 & & & & & \\
\hline
\end{tabular}

$\mathrm{B}=$ regression coefficient, $\mathrm{SE}=$ standard error, Wald $=$ Wald statistic, $95 \% \mathrm{CI}=$ 95\% confidence interval.

After adjustment for other variables, obesity was not an independent predictor for a positive anti B2glycoprotien - 1, IgG and/or IgM (all p- values $>0.05)$.

\section{DISCUSSION}

A major cause of morbidity and mortality of the antiphospholipid syndrome (APS) is the occurrence of thrombotic events (Felipe et al., 2014).

Obesity is an established risk factor for thrombosis; it is related with adverse pregnancy outcome. Coexistence of obesity with antiphospholipid syndrome (APS) raises the risk of developing thrombosis. (Cedergren, 2004).

This current study evaluate the impact of obesity as a risk factor of

(APS) by comparing incidence of pregnancy morbidities (REM, PMBIUFD), PTE, vascular events and presence of:

- Anti-cardiolipinIgG and/or IgM measured by standardized non cofactor dependent ELISA on 2 or more occasions, not less than 12 weeks a part: medium or high titre (i.e> the 99thpercentile).

- Lupus anticoagulant detected on 2 occasions not less than 12 weeks a part 
according to the guidelines of international society of thrombosis andhemostasis.

Anti-B2 glycoprotein-1 IgG and/or IgMisotype in serum or plasma in titre> the 9th percentile) present on two occasions at least twelve weeks apart measured by a standardized ELISA.

In two groups of women who were previously diagnosed as (APS) cases according to Sydney's criteria.

- First group consists of 30 patients who have normal(BMI) $<30$. This group is considered as control group (reference group).

- Second group consists of 30 patients who have (BMI) $>30 \mathrm{Kg} / \mathrm{m} 2$.

Table 1 describes the relation between obesity and presentation of the disease. The table shows that there is no statistically significant difference in age between obese group and no obese group ( $\mathrm{P}$ value 0.53 ) (the obese group).

But there is significant difference in duration of disease between the previous two groups $\mathrm{p}$ value 0.022 . This result disagree with Caldas et al. (2010) who reported that there is no significant difference in age and duration of the disease between obese and non obese group $\mathrm{P}$ value is 0.78 and 0.78 .

Table 1 also shows that there is no significant difference in obstetric event between obese and non obese group ( $\mathrm{P}$ value in case of REM is 0.656 , in case of PMB is 0.181 and in IUFD is 0.179 . this result disagree with Caldas et al. (2010) who reported that obese group had a higher frequency of obstetric event $53.3 \%$ than non obese group $22.8 \%$ p value 0.04 . 
This table also shows that there is no significant difference in the incidence PTE between obese and non obese group $43.3 \%$ and $28.3 \%$ respectively $\mathrm{P}$ value is 0.165 . This result disagree with Caldas et al. (2010) who reported that there is significant difference in the incidence of PTE between obese and non obese group $96.6 \%$ and $14.2 \%$ respectively p value is 0.022 .

In case of vascular event table (1) show that there is no significant difference between obese and non obese group $30 \%$ in both groups p value.

This agree with Caldas et al. (2010) show reported that there is no significant difference in vascular event between obese and non obesegroup.

The result of laboratory characteristics of (APS) patients obese and non obese show that LAC was more frequent in non obese (APS) patients than obese are $86.7 \%$ in non obese group and $53.3 \%$ in obese group Pvalue

0.001. On other hand there is no significant difference between obese and non obese group in other laboratory criteria. This result agree with Caldas et al. (2010) who reported that the incidence of LAC in non obese group (94.2\%) is higher than obese group (53.340) $\mathrm{P}$ value is 0.01 and there is no significant difference between obese group and non obese group in other laboratory criteria (Caldas et al. (2010) explained this finding by comparing with some data from previous literature that show a lower prevalence of antinuclear antibodies in women with overweight or obesity (Conzalez et al., 2008), being speculated the role of leptin resistance in obese individuals, could impair antinuclear antibodies production by B lymphocytes (Brito et al.,2006). 
A multivariable binary logistic regression analysis for relation between obesity and criteria of the disease was done and showed the following data:

Table 2: as regard REM: Obesity was not an independent predictor factor for REM.

Table 3: as regard PMB.: Obesity was an independent predictor for PTB (odd ratio 5.998, $(95 \% \mathrm{CI}=1.395-26.752) \mathrm{p}$ value 0.019 . This agree with Cnattingius et al. (2013) who reported that as compared with normal weight women rates $(\%)$

and adjusted odd ratios (Ors, (95\% CI) of extremely preterm delivery were as follow BMI 25 to less than 30 (0.21\%, OR 1.26, 95\% (CI 1.15-1.37).

BMI 30 to less than 35 (0.27\%, OR $1.5895 \%$ (CI, 1.39-1.79) BMI 35 to less than $40(0.35 \%$ OR, 2, 2.01, 95\% (CI 1.6-2.45) and BMI of 40 or greater

(0.52\%, OR 2.99 95\% (CI 2.28-3.92).

On the other hand age was independent predictor for PTB odd ratio = $0.65,95 \%, \mathrm{CI}=0.780$ to $0.959 \mathrm{p}$ value 0.006 . This agree with Hediger et al. (1997) who reported that after adjusting for all risk factors young adolescent overall had a nearly $75 \%$ increased risk of PMB (adjusted odds ratio - 1.74) (95C3 1.07-2.84).

Table 4: as regard IUFD.: Obesity was independent predictors for IUFD odds ratio $=10.087,(95 \% \mathrm{CI}=1.712$ to 59.448$)$. $\mathrm{p}$ value 0.011 . this agree with Tennant et al. (2011) who reported that obese women were at significantly increased risk of fetal death (adjusted odd ratio $=2.32(95 \%$ CI 1.64-3.28) $\mathrm{P}$ $<0.001$. 
On the other hand older age was independent predictor for IUFD odds ratio-1.137, 95\% CI 1.02-1.264) $\mathrm{P}$ value 0.018. this agree with Bateman (2006) who reported that the odds ratio for stillbirth 1.28 (95\% CI, 1.24-1.32) in women aged 35-39 years and 1.72 (95\% CI 1.6-1.81) in women aged 40 years or older compared with 20-34 years oldwomen.

Table 5 as regard PTE: Obesity was also independent predictor for PTE odd ratios 40.690, 95\% (CI 3.057-541.690) p value 0.005. This agrees with Friend and Kakker (1970) who demonstrated that the risk of pregnancy associated pulmonary embolism (PAPE) is increase with obesity (BMI $\geq 30 \mathrm{~kg} / \mathrm{m} 2$ ) but disagree with Min et al. (2014) who reported that in analysis of BMI at delivery women with BMI of 25 to 29 showed higher prevalence than women with BMI greater than 30 (7 vs 5 cases).

Older age was independent predictor for PTE odd ratio $=1.283395 \%$ $(\mathrm{CI}=1.107-1.487) \mathrm{P}$ value 0.001 this agree with Min et al. (2014) who reported that the prevalence of pregnancy associated pulmonary embolism (PAPE) was high in advanced maternal age(46.2\%).

Table 6 as regard vascular event: This study showed that obesity was not an independent predictor for vascular events ( $\mathrm{p}$ value $>0.05$ ). This disagrees with Klovaite et al. (2015) who reported that risk of DVT increased with increasing BMI (P Trend < 0.001).

Table 7, 8, 9, 10 laboratory criteria: Obesity was not an independent predictor for a positive LAC test (table 7), positive acLIgG test (table 8), positive acLIgG test (table 9), or anti- $\beta 2$ glycoprotein-1 IgG and IgM(table 10), (all p- value>0.05). 
This disagrees with Caldas et al. (2010) who reported that LAC was more frequent in non-obese primary antiphospholipid patients (PAPs) patient than obese ones $\mathrm{P}$ value $<0.01$.

\section{RECOMMENDATIONS}

Patient with APS need to take all possible measures to lower the risk of developing blood clots. This includes: maintaining a healthy body weight, no smoking and remaining physically active.

\section{REFERENCES}

Alijotas-Reig J, Ferrer-Oliveras R, EUROAPS Study Group (2012): The European Registry on Obstetric Antiphospholipid Syndrome (EUROAPS): a preliminary first year report. Lupus;21:766-8.

Alijotas-Reig J, Ferrer-Oliveras R, Ruffatti A, Tincani A, Lefkou E and Bertero MT. (2014): The European Registry on Obstetric Antiphospholipid Syndrome (EUROAPS): A survey of 247 consecutive cases. http://dx.doi.org/10.1016 j.autrev.2014.12.010.

Bateman BT (2006): Stillbirth at the extremes of reproductive age a large nationwide sample of deliveries in the United States. Am J ObstetGynecol; 194:840-5.

Brito Diaz B, Rodriguez Pérez MC and Cabrera de Le n A (2006): The vicious circle of leptin and obesity. CurrNutr Food Sci; 2:361-73.

Caldas L, Cezar A, Maria HM and Jozélio FC (2010): Obesity in primaryantiphospholipid syndrome is associated with worse outcome ; 78:319-325.

CedergrenMJ (2004): Maternal morbid obesity and risk of adverse pregnancy outcome. ObesGynecol ; 103: 219-24. 
Cervera R, Bucciarelli S, Plasin MA, Gomez-Puerta JA, Plaza J, Pons- Estel G, Choenfeld Y, Ingelmo M and Espinos G. (2009). Catastrophic Antiphospholipid syndrome (CAPS): descriptive analysis of 280 patients from the "CAPS Registry". J Autoimmun; 32(3-4):240-5.

Cervera R, PietteJc, Font J, Khamashta MA, Shoenfeld Y, Camps MT, Saren J and Gabriella L. (2002): Antiphospholipid syndrome: clinical and immunologic manifestations and patterns of disease expression in a cohort of 1,000 patients. Arthritis Rheum; 46:1019- 1027.

Charles J Lockwood \& Michael D Lockshin (2017): Pregnancy in women with antiphospholipid syndrome. Am J ObstetGynecol; 181:6454 .

Cnattingius S, Villamor E, Johansson S, AK, Persson M, Wikström AK and Granath F (2013): Maternal obesity and risk of preterm delivery. JAMA;309(22):2362-70.

Conzalez DA, De Le on AC and Rodriguez Pérez MC.(2008):Inverseassociation between obesity and antinuclear antibodies in women. J Rheumatol;35:2449-51.

Espinosa G, Cervera R, Font J and Asherson RA (2002): the lung in the antiphospholipid syndrome. Ann Rheum Dis; 61:195-198.

Felipe FS, Roger AL and Jozélio FC (2014): Cardiovascular risk factors inantiphospholipid syndrome. Journal of Immunology Research Volume 2014, Article ID621270.

Friend JR and Kakkar VV (1970): The diagnosis of deep vein thrombosis in the puerperium. BJOG: Brithish Journal of Obstetrics \&Gynaecology; 77(9):820-3.

Giannakopoulos B and Krilis SA (2013): The pathogenesis of the antiphospholipid syndrome. N Engl J Med 368(11): 1033-1044.

Hediger ML, Scholl TO, Schall JI, Krueger PM, Young (1997):

Maternal age and preterm labor. Ann Epidemiol; 7(6):400-6.

Klovaite J, Benn M and Nordestgaard BG (2015): Obesity as a causal risk factor for deep venous thrombosis: a Mendelian randomization study. Journal of Internal Medicine;277(5):573-84. 
Lockshin MD, Miyakis S and Atsumi T. (2006): international consensus statement on an update classification criteria for deficiteantiphospholipid syndrome (APS). J ThrombHaemost; 4:295-306.

Marchetti T, Cohen M, and de Moerloose P (2013): Review Article Obstetrical Antiphospholipid Syndrome: From the Pathogenesis to the Clinical and Therapeutic Implications. Clinical and Develomental Immunology volume 2013, Article ID 1591249.

Min-Young L, Moon-Young K, Jung-Yeol H, Jeong-Bae P, Kyung SL and Hyun-Mee R (2014): Pregnancy-associated pulmonary embolism during the peripartum period: An 8-year experience at a single center. ObstetGynecolSci; 57(4):260-265.

Nayer A and Ortega LM (2014): Catastrophic Antiphospholipid syndrome: a clinical review. J Nephropathol; 3(1):9-17.

Tennant PW, Rankin J and Bell R (2011): Maternal body mass index and the risk of fetal and infant death: a cohort study from the North of England. Hum Reprod; 26(6):1501-11.

Ye Z, Yu W, Hsueh C, Leu H, Chen J and Lin S (2005): Antiphospholipid Syndrome presenting as Intracrdiac Thrombus With Pulmonary Embolism. Circ J; 69:1290-1292. 


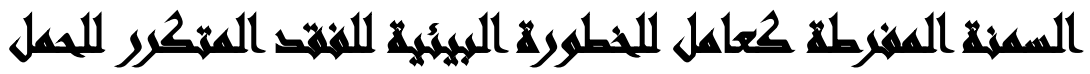

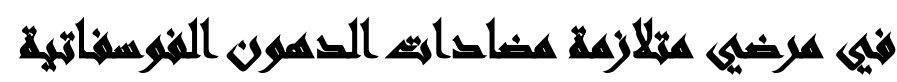

\section{[}

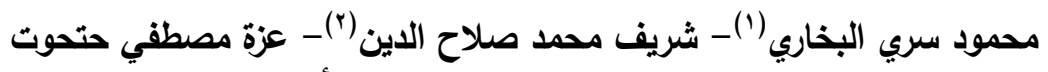

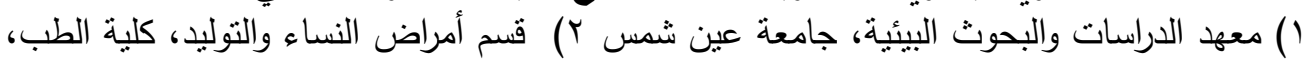

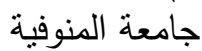

\section{المستخليف}

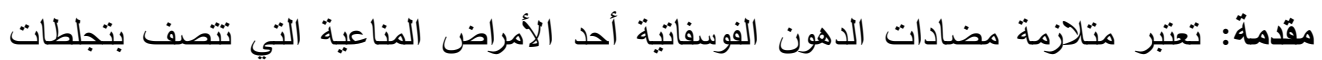

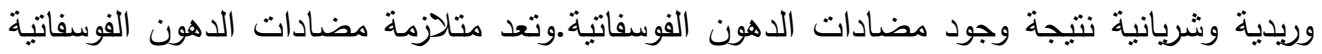

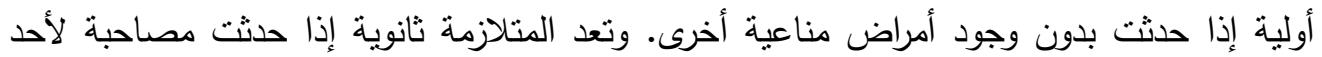

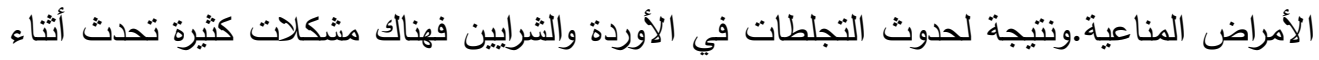

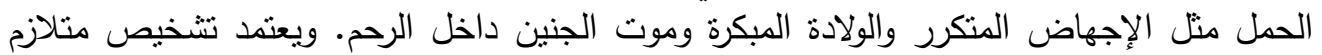

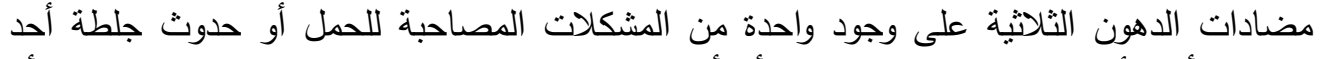

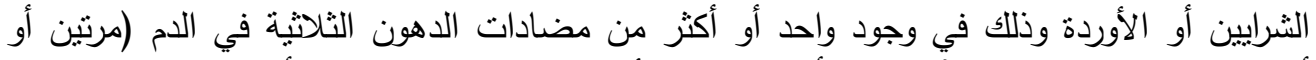

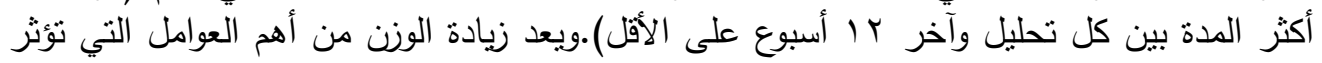

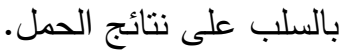
الهدف من الاراسة: دراسة تأثير زيادة الوزن على نتائج الحمل والصفات الإكلينيكية وكذللك نتائج

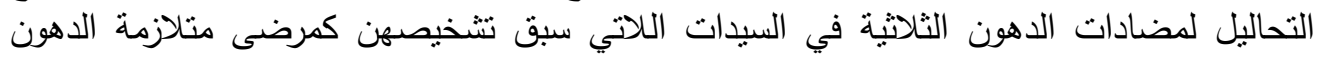
الثلاثية. ونظراً لندرة ذلك المرض فقد نم جمع الحالات من ثلاثة مستشفيات وهم مستشفي بولاق الدكرور

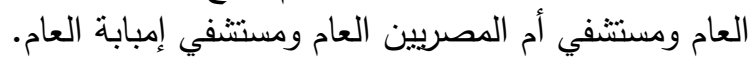

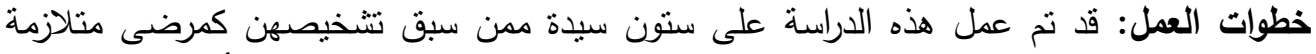

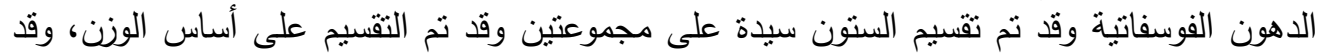

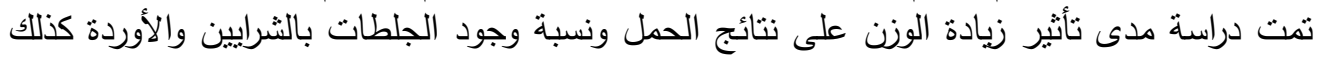

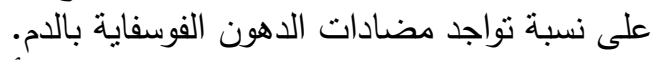

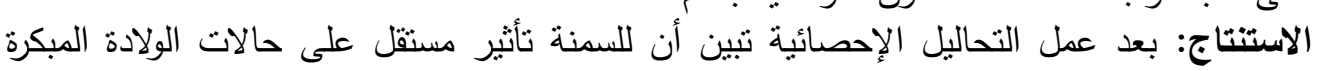
وموت الجنين داخل الرحم. 